\title{
Erratum
}

\section{Probiotics and constipation: mechanisms of action, evidence for effectiveness and utilisation by patients and healthcare professionals - ERRATUM}

\author{
Eirini Dimidi, S. Mark Scott and Kevin Whelan
}

doi: 10.1017/S0029665119000934, Published online by Cambridge University Press, 2 July 2019

The above published article omitted that it was part of the International Early Research Championship.

Original Text (page 1)

The Nutrition Society Winter Meeting was held at the Royal Society of Medicine, London on 4-5 December 2018

Conference on 'Optimal diet and lifestyle strategies for the management of cardio-metabolic risk'

\section{Correction}

The Nutrition Society Winter Meeting was held at the Royal Society of Medicine, London on 4-5 December 2018

Conference on 'Optimal diet and lifestyle strategies for the management of cardio-metabolic risk'

International Early Research Championship

\section{Reference}

Dimidi E, Mark Scott S \& Whelan K (2019) Probiotics and constipation: Mechanisms of action, evidence for effectiveness and utilisation by patients and healthcare professionals. Proceedings of the Nutrition Society, 1-11. doi:10.1017/S0029665119000934 